\title{
Konflikty interesów publicznych w związku z działalnością wydobywczą kopalń węgla kamiennego
}

\section{Uwagi ogólne}

Działalność górnicza niezbędna jest dla zabezpieczenia interesów państwa, jako całości, i zachowania jego bezpieczeństwa energetycznego. Złoża węgla różnego rodzaju są dobrem narodowym, jednak wyczerpywalnym. Z jednej strony należy o nie dbać, prowadząc racjonalną gospodarkę wydobywczą, zwłaszcza w kontekście konstytucyjnej zasady zrównoważonego rozwoju ${ }^{1}$, z drugiej strony należy być świadomym możliwych konfliktów interesów rodzących się na tle tak prowadzonej działalności. Działalność wydobywcza nie jest bowiem obojętna ani dla środowiska, ani dla interesów różnych podmiotów. Chodzić może zarówno o interesy indywidualne, jak i publiczne. Szczególnie interesującym przypadkiem może być konflikt interesów publicznych Skarbu Państwa oraz jednostek samorządu terytorialnego, które narażone są na negatywne skutki funkcjonowania kopalń2 ${ }^{2}$ Podobne konflikty interesów pojawiają się w relacjach

1 Por. G. Dobrowolski, The role of the principle of sustainable development in the legal regulation of geology and mining, „Prawne Problemy Górnictwa i Ochrony Środowiska” 2019, nr 1 , s. $45-54$.

2 Termin „kopalnia” ma charakter normatywny, występuje w przepisach krajowych oraz międzynarodowych, zatem będę się nim posługiwał. Mam świadomość, że niektóre regulacje z zakresu prawa górniczego posługują się terminem ,zakład górniczy”. Moje opracowanie ma jednak charakter szerszy. 
pomiędzy Unią Europejską a niektórymi państwami członkowskimi, opierającymi swe bezpieczeństwo energetyczne na węglu. Takimi właśnie analizami, choć zawężonymi do niektórych tylko aspektów, chciałbym zająć się w niniejszym opracowaniu.

W pierwszej kolejności należy jednak omówić pewne zagadnienia ogólne, definicyjne i systematyzujące.

\section{Rozumienie „interesu” oraz „konfliktu interesów”}

Termin „interes” (łac. interesse: „być pomiędzy”, „być w czymś”, „znajdować się przy czymś”, „być obecnym”, „brać udział”"), dość często pojawiający się w języku, także prawnym oraz prawniczym, ma długą tradycję, nie ma jednak jednego, ustalonego znaczenia. Jego definicje dość znacznie różnią się od siebie. Ten stan rzeczy wynika głównie z różnorodności funkcji, jakie interesujący termin pełni w poszczególnych wypowiedziach. Występuje on także w języku potocznym, co wzmacnia jego wieloznaczność. Nierealne jest więc podanie jednej definicji ,interesu”, która objęłaby wszelkie możliwe przypadki. Warto jednak przedstawić wybrane koncepcje, gdyż nieco przybliżą nam one omawianą problematykę.

Do grona nowożytnych prekursorów zainteresowań problematyką interesu na gruncie różnych dziedzin nauki zalicza się oświeceniowych encyklopedystów francuskich - Helwecjusza i Diderota, angielskich ekonomistów A. Smitha i D. Ricardo oraz przedstawiciela utylitaryzmu J. Bentahama, według którego interes społeczeństwa to suma interesów jednostek. O zagadnieniach tych pisał też N. Machiavelli' ${ }^{4}$.

Interes określa się niekiedy w słownikach jako zależność pomiędzy osobą a wynikiem jakiejś toczącej się sprawy, polegającą na korzyści (także niewymiernej), jaką ta osoba może odnieść przy odpowiednim rozstrzygnięciu (rezultacie, wyniku) sprawy. Posiadanie interesu może objawiać się w czynnym uczestnictwie w sprawie i oddziaływaniu na nią bądź w samym oczekiwaniu na rozstrzygnięcie . Interes to też „sprawa do załatwienia, pożytek, korzyść,

\footnotetext{
3 Prawo rzymskie. Stownik encyklopedyczny, red. W. Wołodkiewicz, Wiedza Powszechna, Warszawa 1986, s. 77; J. Drążkiewicz, Interesy a struktura społeczna, PWN, Warszawa 1982, s. 5.

${ }^{4} \mathrm{M}$. Stefaniuk, Interes państwa i jego odpowiedniki w orzecznictwie polskiego Trybunatu Konstytucyjnego, w: Pojęcie interesu w naukach prawnych, prawie stanowionym i orzecznictwie sadowym Polski i Ukrainy, red. A. Korybski, M.W. Kostyckij, L. Leszczyński, Wydawnictwo Uniwersytetu Marii Curie-Skłodowskiej, Lublin 2006, s. 233.

5 P.J. Suwaj, Konflikt interesów w administracji publicznej, Wolters Kluwer Polska, Warszawa 2009, s. 19.
} 
przedsięwzięcie przynoszące korzyść materialną, sklep, przedsiębiorstwo", a w innym ujęciu ,przedmioty lub stany rzeczy, których osiągnięcie jednostki lub grupy społeczne uważają za pożądane lub konieczne i dla osiągnięcia których mobilizują swą aktywność i środki" może też dodatni bilans zysków i strat.

Ekonomia rozumie przez interes obiektywne stany rzeczy stanowiące przedmiot dążeń jednostek lub grup gospodarujących ${ }^{8}$. Określa się go także niekiedy jako społeczną relację między potrzebami a dobrami; powstaje on wskutek działania podobnego rodzaju potrzeb, a ściślej — potrzeb grupy jako całości ${ }^{9}$.

Za podstawę interesu można przyjąć, po pierwsze, pewien rodzaj wartości (coś jest interesem danego podmiotu ze względu na pewną wartość). Stan rzeczy lub przedmiot zostaje uznany za interes podmiotu, ponieważ jest on wartościowy, korzystny, dla niego. Taką podstawę interesu można nazwać aksjologiczną. Skrajne stanowisko terminy „,interes” oraz ,wartość” traktuje jako synonimy. „Odnoszenie pojęcia interesu do pewnego rodzaju wartości następuje bardzo często w koncepcjach posługujących się kategorią »interesu publicznego«"10.

Po drugie, podstawą interesu może być potrzeba lub zbiór potrzeb (coś jest interesem danego podmiotu ze względu na pewną potrzebę). Koncepcja ta miała na celu uniknąć uwikłania w aksjologię, stąd zyskała wielu zwolenników. Część autorów wręcz utożsamiała interes z potrzebą, twierdząc np., że interesy to społecznie zdeterminowane potrzeby ${ }^{11}$, a część je wyraźnie oddzielała, z tym, że sama potrzeba była przez nich rozumiana różnie: albo subiektywnie (jako życzenie, odczuwane pragnienie), albo obiektywnie (gdy potrzebę występującą w podstawie interesu ujmowano niezależnie od wyobrażeń i subiektywnych przekonań poszczególnych osób) ${ }^{12}$.

Po trzecie wreszcie, jako podstawę interesu widziano kategorię celu (coś jest interesem danego podmiotu ze względu na pewien cel). Tego rodzaju podstawę interesu nazywa się prakseologiczną. Zwolennikiem takiego podej-

${ }^{6}$ Stownik języka polskiego Wydawnictwa Naukowego PWN, https://sjp.pwn.pl/szukaj/interes.html [dostęp: 13.03.2021].

${ }^{7}$ Nowy Leksykon PWN, red. A. Dyczkowski, PWN, Warszawa 1998, s. 684.

${ }^{8}$ Encyklopedia popularna PWN, red. A. Karwowski, PWN, Warszawa 1982, s. 296.

9 J.P. Gieorgica, Pojęcie interesu w marksistowskiej nauce o polityce, w: Z zagadnień teorii polityki, red. K. Opałek, PWN, Warszawa 1978, s. 209.

10 J. Drążkiewicz, Interesy a struktura społeczna..., s. 26.

${ }^{11}$ T. Rowiński np. stwierdza, że ,interes” i „potrzebę” powinno się traktować jako synonimy (T. Rowiński, Interes prawny $w$ procesie cywilnym $i w$ postępowaniu nieprocesowym, Wydawnictwo Prawnicze, Warszawa 1971, s. 18).

12 Por. M. Misztal, Problematyka wartości w socjologii, PWN, Warszawa 1980, s. 127-139; J.J. Wiatr, Spoleczeństwo. Wstę do socjologii systematycznej, Warszawa 1977, s. 197-198; R. Flathman, The Public Interest, John Wiley \& Sons, Inc., New York-London-Sydney 1966, s. 15-16; J. Drążkiewicz, Interesy a struktura spoteczna..., s. 20 i nast.; V. Held, The Public Interest and Individual Interests, Basic Book, New York-London 1970, np. s. 51. 
ścia jest m.in. J. Mucha. Jego zdaniem, relatywizacja interesu pewnego podmiotu w stosunku do celów tego podmiotu jest ważniejsza niż relatywizacja w stosunku do „udziału w dobrach (wartościach)”, ponieważ zwiększający się udział podmiotu (grupy) w dobrach nie zawsze jest korzystny z punktu widzenia jego dalszych, na ogół ważniejszych, celów ${ }^{13}$. Pisał również: „[...] sam byłbym skłonny interesem grupy nazwać taki stan społeczny (sytuację społeczną), który byłby środkiem realizacji danych celów grupy. Cele te mogą być mniej lub bardziej dalekosiężne"14. Jednocześnie definicje interesu przyjmujące podstawę prakseologiczną mogą w swej najbardziej formalnej wersji abstrahować od wartości ${ }^{15}$.

Różnorodne interesy mogą pozostawać w sytuacji konfliktowej. Źródłosłowu „konfliktu” szukać należy w łacińskim słowie conflictus, oznaczającym zderzenie. Konflikt jest zetknięciem się sprzecznych dążeń, niezgodnością interesów, poglądów. To antagonizm, kolizja, spór, zatarg. Może być też rozumiany psychologicznie, jako sprzeczność powstająca w przypadku zaistnienia u kogoś co najmniej dwu potrzeb, których jednoczesne zaspokojenie nie jest możliwe. W socjologii opisuje się także konflikt społeczny, oznaczający relacje między grupami lub klasami społecznymi, wynikający ze sprzeczności ich żywotnych interesów, a także ze sprzeczności wartości i celów uznawanych przez te grupy ${ }^{16}$.

P.J. Suwaj stwierdza, że konflikt w najszerszym ujęciu obejmuje takie pojęcia, jak: sprzeczność, rywalizacja, konkurencja, protest, napięcie, walka, antagonizm, zatarg. Definicje szerokie odnoszą się do różnorodnych sprzeczności celów i interesów. Podkreślają złożoną strukturę sytuacji, jej dynamikę i interakcyjność oraz różnice interesów jako przyczyny konfliktu ${ }^{17}$. Sama badaczka przyjmuje, że konflikt to sprzeczność tkwiąca w danej sytuacji, polegająca na niemożności jednoczesnej realizacji wszystkich interesów ${ }^{18}$.

13 J. Mucha, Konfliktowe modele społeczeństwa we współczesnej socjologii niemarksistowskiej — próba typologii, „Studia Socjologiczne” 1975, nr 1, za: J. Drążkiewicz, Interesy a struktura spoteczna..., s. 28.

${ }_{14}$ J. Mucha, Konflikt i społeczeństwo: z problematyki konfliktu społecznego we współczesnych teoriach zachodnich, PWN, Warszawa 1978, s. 20.

15 J. Drążkiewicz, Interesy a struktura społeczna..., s. 30. S. Ehrlich stwierdzał, przyjmując, jak się wydaje, takie założenia, że: „Motorem grupowania się ludzi dla wspólnego działania jest jakiś interes, to jest świadome dążenie do wspólnego celu. Interes taki powoduje, że ludzie organizują się, aby go realizować" (S. Ehrlich, Władza i interesy. Studium struktury politycznej kapitalizmu, PWN, Warszawa 1974 [I. wyd. 1967], s. 34).

16 Stownik wyrazów obcych, red. J. Tokarski, PWN, Warszawa 1972, s. 378. Por. np. Interesy i konflikt. Studia nad dynamika struktury społecznej w Polsce, red. W. Adamski, Zakład Narodowy im. Ossolińskich, Wrocław-Warszawa-Kraków 1990.

17 P.J. Suwaj, Konflikt interesów w administracji publicznej..., s. 36-37.

18 Ibidem, s. 39. 
M. Wyrzykowski przez konflikt rozumie natomiast taki układ wzajemnych wartości (lub potrzeb), w którym wartości te wykluczają się bądź realizacja jednych utrudnia realizację innych ${ }^{19}$.

Można również dokonywać klasyfikacji różnych konfliktów. Wśród nich, dla przykładu, wyróżnia się konflikty między: osobami, grupami, organizacjami, a także między osobami a grupami, między osobami a organizacjami, między grupami a organizacjami. Według innego podziału konflikty dzieli się na: ekonomiczne, polityczne, ideologiczne, kulturalne, a nawet religijne.

Zdaniem M. Wyrzykowskiego występowanie konfliktów jest jednak oznaką żywotności społeczeństwa i nie jest niczym negatywnym. Rzecz zaś w tym, by po pierwsze - tworzyć warunki i mechanizmy, w których organy państwa w jak najmniejszym stopniu będą tworzyły źródła konfliktów, po wtóre — należy tworzyć reguły i mechanizmy oraz próbować tworzyć kryteria rozstrzygania konfliktów. Państwo, jego zdaniem, nie jest osłabiane przez konflikty, mają one bowiem charakter zjawiska obiektywnie występującego, choć z różnym natężeniem. Natomiast czynnikiem osłabiającym państwo jest brak lub niewystarczający poziom mechanizmów ich rozstrzygania ${ }^{20}$.

Konflikty interesów, bądź wartości, są przy tym jednymi z możliwych rodzajów konfliktów i nie wyczerpują pełnego ich katalogu. Mają jednak ogromne znaczenie społeczne, wpływając na prawo, politykę, relacje międzyludzkie oraz między innymi podmiotami, w tym osobami prawnymi. Determinują stosunek obywateli do samorządu terytorialnego i państwa oraz do administracji, realizującej określone założenia, w tym polityczne ${ }^{21}$.

Zadaniem władz jest więc stworzenie i wdrożenie w życie mechanizmów pozwalających konflikty różnego rodzaju łagodzić. Całkowite ich wyeliminowanie nie będzie oczywiście możliwe, a nawet nie byłoby wskazane, w czym podzielam pogląd M. Wyrzykowskiego, w pewnym zakresie konflikty wartości lub interesów są bowiem motorem postępu, rozwoju, zdrowej konkurencji, twórczej wymiany poglądów, itd. Chodzi jedynie o to, by sprowadzać je do bezpiecznego poziomu.

Instytucjonalne rozstrzyganie konfliktów interesów lub wartości, wiążąc się z ich wyważaniem, odbywa się zasadniczo na dwóch poziomach. Pierwszym jest tworzenie prawa, a drugim jego stosowanie i egzekwowanie. W pierwszym przypadku szczególna rola przypada nie tylko prawodawcy, ale i Trybunałowi Sprawiedliwości Unii Europejskiej oraz trybunałom konstytucyjnym poszczególnych państw, a w drugim — administracji i sądownictwu.

${ }_{19}$ M. Wyrzykowski, Pojęcie interesu społecznego w prawie administracyjnym, Wydawnictwo UW, Warszawa 1986, s. 164.

20 Ibidem.

${ }_{21}$ Zob. np. J. Łętowski, Administracja i obywatele (refleksje rocznicowe), „Państwo i Prawo” 1984, nr 7; Idem, Administracja. Prawo. Orzecznictwo sądowe, Zakład Narodowy im. Ossolińskich, Wrocław-Warszawa-Kraków-Gdańsk_-Łódź 1985, s. 34. 
Warto zwrócić uwagę, że w literaturze pisano nie tylko o konflikcie interesów, ale też o konieczności „równoważenia interesów”. J. Habermas, analizując przeobrażenia sfery publicznej, zauważał: „Sfera publiczna obciążona jest teraz zadaniem równoważenia interesów, które wymyka się klasycznym formom porozumień i uzgodnień parlamentarnych; problem równoważenia interesów niejako nosi widome ślady swego rynkowego pochodzenia — równowagę interesów trzeba dosłownie »negocjować«, tworzyć drogą nacisków i kontrnacisków na zawołanie, tylko w oparciu o chwiejną równowagę konstelacji władzy pomiędzy aparatem państwowym i grupami interesu. Polityczne decyzje podejmowane są w trybie »przetargu« [...], nowej formie sprawowania władzy, jaka wykształciła się obok form dawniejszych — hierarchii i demokracji. Owszem, z jednej strony zakres kompetencji sfery publicznej poszerzył się. Ponieważ jednak z drugiej strony równowaga interesów podlega liberalnemu wymogowi, zgodnie z którym uprawomocnieniem sfery publicznej jest wzgląd na dobro powszechne, lecz nie może mu ani sprostać, ani się od niego całkiem uwolnić, negocjowanie kompromisu przesuwa się do dziedziny pozaparlamentarnej: czy to formalnie, gdy organa państwowe delegują swoje kompetencje na organizacje społeczne, czy to nieformalnie, w drodze faktycznego przeniesienia kompetencji bez formalnego unormowania (albo wbrew niemu)"22.

\section{Konflikty interesów w działalności gospodarczej a ochrona środowiska}

Prowadzenie działalności gospodarczej, zwłaszcza górniczej, wiąże się z koniecznością daleko idącej ingerencji w środowisko, a ono stanowi wartość chronioną konstytucyjnie i traktatowo. To znowuż skutkuje konfliktem różnych wartości i w wielu przypadkach musi prowadzić do ograniczania swobody działalności gospodarczej.

Polityka państwa, uwzględniająca wymogi ochrony środowiska i zasadę zrównoważonego rozwoju (określoną w art. 5 Konstytucji RP), powinna być jednak prowadzona przy możliwie najmniejszej ingerencji $\mathrm{w}$ wolności i prawa jednostki, w tym w wolność działalności gospodarczej, a więc zgodnie z zasadą proporcjonalności. Ingerencja ta w sferze gospodarczej jest jednak konieczna i przybiera różnorodne postaci, np.:

1) wprowadzanie reglamentacji działalności gospodarczej ingerującej w środowisko, poprzez obowiązek uzyskiwania stosownych koncesji, zezwoleń, itd.

${ }^{22}$ J. Habermas, Strukturalne przeobrażenia sfery publicznej, PWN, Warszawa 2007, s. 363-364 i podana tam literatura. 
Jedne zasady dotyczyć muszą przedsiębiorców chcących prowadzić działalność gospodarczą polegającą na bezpośrednim eksploatowaniu dóbr naturalnych, a inne przypadków takich, gdy istotą nie jest eksploatacja ww. zasobów (jedynie ubocznym efektem tej aktywności jest oddziaływanie na środowisko). Daleko idąca ingerencja ustawodawcy dotyczyć musi działalności polegającej na eksploatacji zasobów przyrodniczych, szczególnie tych, które są zasobami nieodnawialnymi (np. kopaliny ${ }^{23}$ ). Im bardziej ceniony lub trudniej odnawialny element środowiska, tym głębszej ingerencji w sferę wolności działalności gospodarczej należy się spodziewać;

2) nakładanie na przedsiębiorców różnorodnych obciążeń finansowych (np. opłat za korzystanie ze środowiska) - Trybunał Konstytucyjny w swym wyroku z dnia 9 lutego 1999 r. (sygn. akt U 4/98) ${ }^{24}$, rozpatrując konstytucyjność opłaty eksploatacyjnej nakładanej na przedsiębiorców wydobywających kopalinę oraz przedsiębiorców wydobywających surowiec mineralny $\mathrm{z}$ odpadów po robotach górniczych lub w procesach wzbogacania kopalin, uznał wręcz za oczywiste wprowadzanie obowiązku opłat za korzystanie ze środowiska;

3) nakładanie na przedsiębiorców obowiązków o charakterze dokumentacyjno-sprawozdawczo-informacyjnym;

4) wprowadzenie odpowiedzialności za szkody powstałe w środowisku — podstawę konstytucyjną stanowi tu art. 86. Przepis ten ustanawia zasadę odpowiedzialności każdego, w tym przedsiębiorców, za pogorszenie środowiska, odsyłając jednocześnie do ustaw zwykłych;

5) nakładanie na przedsiębiorców obowiązków związanych z zakończeniem działalności gospodarczej, związanych z koniecznością ochrony środowiska ${ }^{25}$.

Pośrednio na działalność gospodarczą wpływać będą także ograniczenia własności wynikające z wymogów ochrony środowiska. Chodzi tu przede wszystkim o ograniczenia wprowadzane na podstawie przepisów o ochronie przyrody oraz wiążące się z możliwością zastosowania przepisów o planowaniu i zagospodarowaniu przestrzennym. Ten ostatni przypadek zostanie rozwinięty w dalszej części opracowania, organy uchwałodawcze jednostek samorządu terytorialnego $\mathrm{w}$ takich planach niekiedy wprowadzają bowiem zapisy ingerujące w działalność górniczą. Jest to efektem kolizyjności różnych interesów publicznych — państwowych i samorządowych.

${ }^{23} \mathrm{~W}$ kwestiach definicyjnych zob. szerzej: G. Radecki, Pojęcie wydobywania kopalin ze złóż w kontekście prawa wodnego, „Prawne Problemy Górnictwa i Ochrony Środowiska” 2020, nr 1-2, s. 131-136; R. Mikosz, Własność kopalin i własność wód-kilka uwag o konstrukcji prawnej, „Prawne Problemy Górnictwa i Ochrony Środowiska” 2020, nr 1-2, s. 63-77.

${ }^{24}$ OTK 1999, Nr 1, poz. 4.

${ }^{25} \mathrm{~Np}$. według art. 37 ust. 1 pkt 6 ustawy z dnia 10.04.1997 r. - Prawo energetyczne (t.j. Dz.U. 2020, poz. 833 ze zm.) koncesja powinna określać m.in. zabezpieczenie ochrony środowiska w trakcie oraz po zaprzestaniu koncesjonowanej działalności. 


\section{Kolizyjność różnych interesów publicznych}

Interes publiczny może mieć różny charakter, może bowiem dotyczyć i państwa, i jednostek samorządu terytorialnego i pewnych, większych lub mniejszych, zbiorowości ludzkich, wyodrębnianych według różnorodnych kryteriów, np. konsumentów. To może prowadzić do sytuacji kolizyjnych.

Niewątpliwie interesy różnego rodzaju powinny być wyważane. Należy sprzeciwiać się wszelkiemu automatyzmowi w rozstrzyganiu tego rodzaju konfliktów i poglądom dającym np. prymat interesowi państwa nad interesami jednostek samorządu terytorialnego. Uważam bowiem, że każdy przypadek winien być rozwiązany z uwzględnieniem jego specyfiki.

Tego rodzaju kolizyjność była przedmiotem analiz dokonywanych przez Trybunał Konstytucyjny. W wyroku z dnia 25 listopada 2003 r. (sygn. akt K 37/02)26 Trybunał wskazał: „W analizowanej ustawie mamy do czynienia z konfliktem różnorodnych interesów publicznych usytuowanych na różnym poziomie, interesu ogólnego oraz interesu określonej społeczności lokalnej. Nie może to jednak prowadzić do wniosku, że owa jednorodność interesu publicznego w zakresie funkcji własności i celu ingerencji może uzasadniać dopuszczalność dowolnego i nieograniczonego wkraczania ustawodawcy w sferę interesów majątkowych jednostki samorządu terytorialnego. Przyjęcie odmiennego stanowiska musiałoby oznaczać, że zawsze ciężar realizacji celów ogólnych może być przenoszony, w całości lub w przeważającej mierze, na określoną społeczność lokalną, a w konsekwencji gwarancje konstytucyjne, wyrażone przede wszystkim przez art. 165 Konstytucji RP w odniesieniu do autonomii prawnej i majątkowej jednostki samorządu terytorialnego, miałyby charakter pozorny".

W tym kontekście nie mogę podzielić stanowiska J. Zimmermanna, który pisał, odnosząc się do interesu lokalnego (również regionalnego), związanego z jednostkami samorządu terytorialnego, że „Na jego tle mogą się [...] pojawiać kwestie kolizyjne $\mathrm{z}$ jednej strony $\mathrm{z}$ interesami indywidualnymi, a $\mathrm{z}$ drugiej z interesem ogólnopaństwowym. Ta ostatnia kolizja powinna być jednak zawsze rozstrzygana na korzyść interesu państwa, gdyż nie może być mowy o przeciwstawianiu państwu samorządu terytorialnego"27. Jednostki samorządu terytorialnego podlegają ochronie konstytucyjnej, tak jak i samo państwo, stąd słusznie Trybunał Konstytucyjny kazał wyważać ich sprzeczne interesy.

Przywołane orzeczenie dotyczyło kolizji interesów publicznych usytuowanych na różnym szczeblu, choć można też wskazać inną konfigurację interesów

${ }^{26}$ OTK-A 2003, Nr 9, poz. 96.

27 J. Zimmermann, Prawo administracyjne, Wolters Kluwer Polska, Warszawa 2012, s. 277-278. Por. również I. Skrzydło-Niżnik, Model ustroju samorzadu terytorialnego w Polsce na tle zagadnień ustrojowego prawa administracyjnego, Wydawnictwo Uniwersytetu Jagiellońskiego, Kraków 2007, s. 236-239. 
publicznych pozostających w konflikcie, odnośnie której Trybunał tak samo tego rodzaju automatyzm wykluczał. Trybunał: „Zwrócił uwagę na to, że ustawodawca cyklicznie staje przed problemem równoważenia różnorodnych interesów publicznych o podobnym znaczeniu i wymiarze dla państwa, wymagających finansowania ze środków publicznych, których wysokość uzależniana jest od dostępnych w tym zakresie i w danym czasie możliwości państwa"28. To równoważenie właśnie wymaga podejmowania różnorakich decyzji legislacyjnych, uwzględniających możliwości budżetowe.

Automatyzmu nie może być też przy rozwiązywaniu konfliktów interesów publicznych, z których oba mają charakter lokalny, co również potwierdza wcześniejszą mą tezę. Tego rodzaju sytuacja była podstawą rozstrzygnięcia przez Trybunał Konstytucyjny w wyroku z dnia 4 listopada 2003 r. (sygn. akt $\mathrm{K} 1 / 03)^{29}$.

Trybunał Konstytucyjny zatem konsekwentnie, od wielu lat po 1989 r., wskazuje, że poszczególne konflikty interesów muszą być rozważnie rozwiązywane z uwzględnieniem specyfiki każdej sprawy i nie może być mowy o jakimkolwiek automatyzmie w tym zakresie. Nie można więc wskazywać abstrakcyjnie, w oderwaniu od konkretnego przypadku, że któryś interes publiczny jest ważniejszy od innego interesu publicznego, nawet jeśli ten pierwszy dotyczy większej społeczności niż drugi. Chodzi tu o oszacowanie korzyści i strat dla poszczególnych grup i wyważenie ich.

Kolizyjność różnych interesów publicznych widoczna jest także na gruncie prawa unijnego. Organy unijne skupiają ogromną uwagę m.in. na sektorze energetycznym, ze względu na jego znaczenie dla funkcjonowania rynku wewnętrznego. Stąd problematyka interesu publicznego wyraźnie jest widoczna w prawodawstwie odnoszącym się do energetyki, przy czym można tu dostrzec pewien dysonans pomiędzy interesem ogólnym Unii a interesami partykularnymi o charakterze narodowym, które również stanowią rodzaj interesu publicznego. Niekiedy nawet podnosi się w literaturze przedmiotu, że część państw członkowskich wciąż nie jest gotowa do faktycznego powierzenia Unii kompetencji w zakresie polityki energetycznej. Państwa te zatem, w sposób mniej czy bardziej jawny, realizują swe interesy narodowe ${ }^{30}$. Wynika to także $z$ dostępu do dóbr określonego rodzaju, np. węgla, które wykorzystywane są w tym sektorze gospodarki do produkcji energii. To z kolei prowadzi do różnej sytuacji kosztowej i konkurencyjności, przez co trudno jest traktować poszczególne państwa członkowskie w sposób jednolity. Stąd instytucje unijne skłonne są w sprawach

${ }^{28}$ A. Wilczyńska, Interes publiczny $w$ prawie stanowionym $i$ orzecznictwie Trybunału Konstytucyjnego, „Przegląd Prawa Handlowego” 2009, nr 6, s. 52. Zob. też wyrok TK z dnia 30.06.2003 r., K 8/02, OTK-A 2003, Nr 6, poz. 57.

${ }^{29}$ OTK-A 2003, Nr 8, poz. 85.

${ }^{30}$ P. Bogdanowicz, Interes publiczny w prawie energetycznym Unii Europejskiej, Wydawnictwo C.H.Beck, Warszawa 2012, s. XV. 
dotyczących swobodnego przepływu uwzględniać racje poszczególnych państw członkowskich w większym stopniu, niż w innych ${ }^{31}$.

\section{Konflikty interesów jednostek samorządu terytorialnego i państwa w związku z wydobyciem węgla}

W praktyce pojawiają się problemy kolizji interesów Skarbu Państwa i jednostek samorządu terytorialnego w związku z działalnością uchwałodawczą tych jednostek, która w pewnym zakresie, poprzez miejscowe plany zagospodarowania przestrzennego, wpływa na sytuację podmiotów prowadzących działalność górniczą, determinując jej zakres i sposób prowadzenia. To z kolei rodzi pytanie o legalność takich aktów prawa miejscowego.

Przykładowo, w pewnym miejscowym planie zagospodarowania przestrzennego ustanowiono zapisy regulujące m.in.: „Granice i sposoby zagospodarowania terenów lub obiektów podlegających ochronie, ustalonych na podstawie odrębnych przepisów, w tym terenów górniczych [...]". Jednocześnie jeden z zapisów wprowadził nakaz zapewnienia nieprzekraczalnych wielkości odkształceń powierzchni: nachylenia powierzchni, promienia krzywizny powierzchni, odkształcenia poziomego powierzchni ${ }^{32}$. Niewątpliwie należy odnieść się krytycznie do tego rodzaju rozstrzygnięć uchwałodawczych. Zapis taki oznacza bowiem de facto zakaz eksploatacji górniczej, która by wartości wskazane w planie miejscowym przekraczała. Żaden przepis prawa powszechnie obowiązującego, kompetencyjnego, nie zezwala organowi uchwałodawczemu gminy na decydowanie o ograniczeniu bądź wyłączeniu eksploatacji górniczej, w zakresie przekraczającym określone parametry.

Art. 15 ust. 2 pkt 7 ustawy z dnia 27 marca 2003 r. o planowaniu i zagospodarowaniu przestrzennym ${ }^{33}$ (dalej u.p.z.p.) wskazuje, że w planie miejscowym określa się obowiązkowo m.in. granice i sposoby zagospodarowania terenów lub obiektów podlegających ochronie, na podstawie odrębnych przepisów, terenów górniczych, a także obszarów szczególnego zagrożenia powodzią, obszarów osuwania się mas ziemnych, krajobrazów priorytetowych określonych w audycie krajobrazowym oraz w planach zagospodarowania przestrzennego województwa. Z kolei pkt 9 tej samej regulacji stwierdza, że określa się tam również szczególne warunki zagospodarowania terenów oraz ograniczenia w ich użytkowaniu, w tym

\footnotetext{
${ }^{31}$ Ibidem.

32 Zob. wyrok WSA w Gliwicach z dnia 16 listopada 2016 r., sygn. akt II SA/G1 932/16,

${ }_{33}$ T.j. Dz.U. 2020, poz. 293 ze zm.
} CBOSA. 
zakaz zabudowy. Z kolei art. 15 ust. 2 pkt 3 u.p.z.p. nakazuje w planie miejscowym określić zasady ochrony środowiska, przyrody i krajobrazu.

Nie są to zatem przepisy precyzyjne. Raczej mają charakter ogólny, kierunkowy. Dlatego nie mogą być odczytywane w oderwaniu od przepisów innych ustaw, w tym ustawy z dnia 9 czerwca 2011 r. - Prawo geologiczne i górnicze ${ }^{34}$ (dalej pr.g.g.), oraz jej zasad. $Z$ podobnych względów nie może mieć tu decydującego znaczenia akt wykonawczy, jakim jest rozporządzenie Ministra Infrastruktury z dnia 26 sierpnia 2003 r. w sprawie wymaganego zakresu projektu miejscowego planu zagospodarowania przestrzennego ${ }^{35}$. Zawiera on pewne regulacje odnoszące się do terenów górniczych ${ }^{36}$, choć również dość ogólne i mało precyzyjne.

$\mathrm{W}$ tego rodzaju sytuacjach powstaje więc problem zakresu kompetencji poszczególnych organów (samorządowych i koncesyjnych), który rodzi się na gruncie konfliktu różnych wartości i interesów: 1) o charakterze lokalnym (związanych z funkcjonowaniem wspólnoty gminnej na obszarze objętym planem) oraz 2) o charakterze ogólnokrajowym.

A. Lipiński wskazuje słusznie, że „Państwo, które dysponuje znaczącymi zasobami węgla, a jednocześnie nie jest w stanie uzyskać stabilnego dostępu do innych nośników energii (np. ropy naftowej, gazu ziemnego), kierując się potrzebą zapewnienia bezpieczeństwa energetycznego ${ }^{37}$, musi takie złoża objąć ochroną pozwalającą na podjęcie ich wykorzystania w przyszłości. [...] Podobnie można ten problem widzieć w odniesieniu do pozostałych złóż kopalin (bezpieczeństwo surowcowe). Oczywiste jest bowiem, że podjęcie wydobycia złoża możliwe jest wyłącznie w miejscu jego występowania; zmiana tej lokalizacji nie jest możliwa. [...] Można co prawda wyobrazić sobie gospodarkę, która w całości oparta jest na wykorzystywaniu surowców mineralnych pochodzących z zagranicy, tyle że rozwiązanie to może okazać się niezmiernie kosztowne, a w dodatku bardzo niebezpieczne" ${ }^{38}$. Przywołany badacz, odnosząc się do

${ }^{34}$ T.j. Dz.U. 2020, poz. 1064 ze zm.

${ }^{35}$ Dz.U. 2003, nr 164, poz. 1587 ze zm.

${ }^{36}$ Np. $\$ 4$ pkt $7, \S 7$ pkt 6 oraz Załącznik nr 1.

${ }^{37} \mathrm{Na}$ zapewnienie bezpieczeństwa energetycznego wpływają czynniki różnego rodzaju, wśród nich zapasy paliw, stabilność dostaw, dywersyfikacja źródeł zaopatrzenia, infrastruktura logistyczna, a nawet ceny paliw i energii (por. M. Kaczmarski, Bezpieczeństwo energetyczne Unii Europejskiej, Wydawnictwa Akademickie i Profesjonalne, Warszawa 2010, passim). Problem bezpieczeństwa energetycznego pojawił się już w 1911 r., kiedy to W. Churchill, sprawujący urząd Pierwszego Lorda Admiralicji, zdecydował, że okręty brytyjskiej marynarki wojennej będą napędzane ropą, a nie jak dotychczas węglem. Chodziło o to, by były one szybsze niż jednostki niemieckie (P. Bogdanowicz, Interes publiczny w prawie energetycznym Unii Europejskiej..., s. 187 i podana tam literatura; A. Żurawik, Interes publiczny w prawie gospodarczym, Wydawnictwo C.H.Beck, Warszawa 2013, s. 359 i nast.).

${ }^{38}$ A. Lipiński, Planowanie przestrzenne jako instrument ochrony złóż kopalin, w: Zrównoważony rozwój jako czynnik determinujący prawne podstawy zarządzania geologicznymi zasobami środowiska, red. G. Dobrowolski, Agencja Reklamowa TOP, Katowice 2016, s. 125. 
przepisów planistycznych, w tym kontekście pisze dalej: „Znane są przypadki wprowadzania zakazu wydobywania kopalin (»blokowanie tworzenia nowych obszarów górniczych «), ograniczenia wielkości oraz technologii wydobycia w sposób nawet rzutujący na właściwość rzeczową organów administracji, czy też zakazu wydobywania kopalin w sposób »mogący powodować deformacje terenu « (co w istocie oznacza całkowity zakaz wydobywania kopalin)"39. Autor ten wskazuje jednocześnie, że nigdy nie można wykluczyć powstania takich deformacji, w tym również nieszkodliwych ${ }^{40}$.

W wyroku NSA z dnia 20 maja 2015 r. (sygn. akt II OSK 394/15) ${ }^{41}$, zwrócono uwagę na przepis $\S 2$ ust. 2 pkt 3 rozporządzenia Ministra Środowiska z dnia 24 kwietnia 2012 r. w sprawie szczegółowych wymagań dotyczących projektów zagospodarowania złóż ${ }^{42}$, który stwierdza, że część opisowa projektów zagospodarowania złóż, z uwzględnieniem zamierzonego sposobu eksploatacji, rodzaju kopaliny i warunków geologicznych prowadzenia eksploatacji, zawiera odpowiednio m.in. uzasadnienie granic zamierzonej eksploatacji, przedstawienie sposobu i miejsca składowania nadkładu, projektowanych filarów ochronnych, ze wskazaniem obiektów objętych ochroną, uzasadnieniem ich granic oraz określeniem warunków ewentualnej eksploatacji złoża objętego filarem ochronnym. NSA stwierdza, że przywołanie ww. przepisu rozporządzenia potwierdza tylko pogląd, iż relacje do nieruchomości znajdujących się na powierzchni ziemi, a co za tym idzie również do sposobów ich zagospodarowania przestrzennego, są skutkiem dalszych etapów prac związanych z eksploatacją złoża. Może mieć to miejsce dopiero na etapie wystąpienia o udzielenie koncesji na wydobywanie kopalin ze złóż, o czym mowa w art. $22-26$ pr.g.g. ${ }^{43}$.

Niewątpliwie nie ma eksploatacji podziemnej bez wpływu na powierzchnię terenu. Nie jest jednak rolą organu uchwałodawczego gminy na etapie przygotowywania i uchwalania planu miejscowego podejmowanie decyzji należących do kompetencji organu koncesyjnego. W tym kontekście należy odczytywać treść art. 15 ust. 2 pkt 3, 7 i 9 u.p.z.p. Gmina może stanowić akty prawa miejscowego tylko w granicach upoważnienia ustawowego i nie może dokonywać wykładni przepisów w sposób pomijający inne uregulowania oraz zasady.

W szczególności istotna tu będzie funkcjonująca na gruncie ustawy - Prawo geologiczne i górnicze, zasada racjonalnej gospodarki złożem kopaliny, obejmująca m.in. nakaz kompleksowego i racjonalnego wykorzystania kopaliny głów-

\footnotetext{
39 A. Lipiński, Planowanie przestrzenne jako instrument ochrony złóż kopalin..., s. 129_130.

${ }^{40}$ Ibidem, s. 130, przypis 23.

41 CBOSA.

42 Dz.U. 2012, poz. 511 ze zm.

43 Por. też art. 30, 32 pr.g.g.; wyrok WSA w Gliwicach z dnia 31 maja 2012 r., sygn. akt II
} SA/G1 363/12; wyrok NSA z dnia 13 listopada 2012 r., sygn. akt II OSK 2443/12; A. Lipiński, Komentarz do art. 22-23 ustawy z dnia 9 czerwca 2011 r. Prawo geologiczne i górnicze, „Prawne Problemy Górnictwa i Ochrony Środowiska” 2020, nr 1—2, s. 41-59. 
nej i kopalin towarzyszących (np. art. 26 ust. 3 i 5, art. 29 ust. 1 pr.g.g.). Są to bowiem tzw. złoża nieodnawialne, występujące tylko i wyłącznie w określonych miejscach, a zatem, jako dobro wspólne, powinny być wykorzystane w sposób maksymalnie efektywny, dla zapewnienia bezpieczeństwa energetycznego kraju oraz interesów przyszłych pokoleń. Jednocześnie przywołany już tu art. 26 ust. 3 pr.g.g. mówi o konieczności dołączenia do wniosku koncesyjnego projektu zagospodarowania złoża, zawierającego m.in. wskazanie technologii eksploatacji zapewniającej ograniczenie ujemnych wpływów na środowisko.

Wyrazem realizacji zasady racjonalnej gospodarki złożem kopaliny jest art. 144 ust. 1 pr.g.g., zgodnie z którym właściciel nie może sprzeciwić się zagrożeniom spowodowanym ruchem zakładu górniczego, który jest prowadzony zgodnie z ustawą. Może on jednak żądać naprawienia wyrządzonej tym ruchem szkody, na zasadach określonych ustawą.

Zatem to organ koncesyjny dokonuje konkretnych ustaleń dotyczących sposobu eksploatacji złoża, także w zakresie ochrony środowiska (art. 30 ust. 2 pr.g.g.). Niespełnienie warunków prawnych skutkuje odmową wydania koncesji (art. 29 ust. $1-3$ pr.g.g.).

W wyroku WSA w Gliwicach z dnia 31 maja 2012 r. (sygn. akt II SA/Gl 363/12), stwierdza się również zasadnie, że podstawy prawnej do wprowadzenia w planie miejscowym ograniczeń dla przyszłej eksploatacji górniczej nie można upatrywać w treści art. 71 ust. 2 pkt 2 i art. 72 ust. 2 ustawy z dnia 27 kwietnia 2001 r. - Prawo ochrony środowiska ${ }^{44}$. Nie chodzi bowiem o warunki realizacji przedsięwzięć umożliwiających uzyskanie optymalnych efektów w zakresie ochrony środowiska. Co więcej, jak dalej twierdzi Sąd, przepis art. 72 ust. 1 pkt 2 tej ustawy nakazuje uwzględnienie w planie miejscowym obszarów występowania złóż kopalin oraz obecnych i przyszłych potrzeb eksploatacji tych złóż, zaś wymagania dotyczące prowadzenia eksploatacji określa projekt zagospodarowania złoża, stanowiący załącznik wniosku o udzielenie koncesji, które to postępowanie podlega regulacji Prawa geologicznego i górniczego. Rada gminy nie jest zatem władna $\mathrm{w}$ drodze aktu prawa miejscowego wprowadzać jakichkolwiek wymogów ograniczających niezasadnie, poza zakresem delegacji ustawowej, możliwość udzielenia koncesji, a jedynie przewidując jej udzielenie w przyszłości oraz uwzględniając skutki prowadzonej w przeszłości eksploatacji górniczej, może wprowadzić szczególne warunki zagospodarowania terenów oraz ograniczenia w ich użytkowaniu, w tym zakaz zabudowy.

Ustawodawca dał organowi wykonawczemu gminy możliwość uzgodnienia udzielenia koncesji na wydobycie kopalin w ramach kryterium nienaruszalności przez eksploatację przeznaczenia nieruchomości określonego w miejscowym planie zagospodarowania przestrzennego (art. 23 ust. 2 a pr.g.g. w zw. z art. 7 ust. 1 pr.g.g.). Podkreślić jednak ponownie należy, że plan miejscowy nie może

${ }^{44}$ T.j. Dz.U. 2020, poz. 1219 ze zm. 
zawierać zapisów, do stanowienia których rada gminy nie jest upoważniona, skoro przepisy powszechnie obowiązujące zastrzegają rozstrzygnięcia w tym zakresie dla organu koncesyjnego.

Nie może mieć również znaczenia przesądzającego fakt, że projekt zagospodarowania złoża zawiera warunki eksploatacji określone przez samego przedsiębiorcę. Organ koncesyjny, mając na uwadze szereg różnych przesłanek ustawowych, decyduje o możliwości udzielenia koncesji i wskazuje na warunki wykonywania działalności wydobywczej. Może również odmówić udzielenia koncesji ${ }^{4}$.

\section{Podsumowanie}

Działalność górnicza niewątpliwie powoduje szereg rozmaitych sytuacji konfliktowych, w różnych aspektach. Jest ona prowadzona na styku prawa prywatnego i publicznego, gdzie sfery te wzajemnie przenikają się. Istotne znaczenie mają także regulacje i wymogi unijne. Należy w ramach tej działalności dbać o środowisko, bacząc przy tym, by gospodarowanie zasobami naturalnymi kraju prowadzone było w sposób racjonalny i zabezpieczało interesy nie tylko obecnego pokolenia, ale i przyszłych generacji. Złoża węgla różnego rodzaju znajdują się w konkretnych miejscach i ilościach, a przez to powinno się dążyć do ich możliwie pełnego wykorzystania, celem zapewnienia bezpieczeństwa energetycznego i uniezależnienia się od dostawców zagranicznych.

Nie może być jednak tak, że interes społeczności lokalnej uniemożliwia realizację wyżej opisanego interesu państwa jako całości. Wyważanie tych interesów polega z jednej strony na zapewnieniu dostępu do złóż, celem ich wydobycia, a z drugiej, na zapewnieniu ewentualnych odszkodowań dla podmiotów pokrzywdzonych eksploatacją górniczą, wraz zapewnieniem im drogi sądowej.

Nie można natomiast stanowić prawa miejscowego w sposób, który faktycznie uniemożliwia prowadzenie działalności wydobywczej i doprowadza do pomijania zasad wskazanych w Prawie geologicznym i górniczym. Zapewnienie bezpieczeństwa surowcowego i energetycznego jest niezbędne nie tylko dla realizacji interesu publicznego - chroni również interesy indywidualne, nawet jeśli niekiedy o tym zapomina się.

${ }^{45}$ Wyrok WSA w Gliwicach z dnia 16 listopada 2016 r., sygn. akt II SA/G1 932/16, CBOSA. 


\section{Literatura}

Bogdanowicz P., Interes publiczny w prawie energetycznym Unii Europejskiej, Wydawnictwo C.H.Beck, Warszawa 2012.

Dobrowolski G., The role of the principle of sustainable development in the legal regulation of geology and mining, „Prawne Problemy Górnictwa i Ochrony Środowiska” 2019, nr 1, s. $45-56$.

Drążkiewicz J., Interesy a struktura społeczna, PWN, Warszawa 1982.

Ehrlich S., Władza i interesy. Studium struktury politycznej kapitalizmu, PWN, Warszawa 1974. Encyklopedia popularna PWN, red. A. Karwowski, PWN, Warszawa 1982.

Flathman R., The Public Interest, John Wiley \& Sons, Inc., New York—London-Sydney 1966. Gieorgica J.P., Pojęcie interesu w marksistowskiej nauce o polityce, w: Z zagadnień teorii polityki, red. K. Opałek, PWN, Warszawa 1978.

Habermas J., Strukturalne przeobrażenia sfery publicznej, PWN, Warszawa 2007.

Held V., The Public Interest and Individual Interests, Basic Book, New York-London 1970.

Interesy i konflikt. Studia nad dynamika struktury społecznej w Polsce, red. W. Adamski, Zakład Narodowy im. Ossolińskich, Wrocław-Warszawa-Kraków 1990.

Kaczmarski M., Bezpieczeństwo energetyczne Unii Europejskiej, Wydawnictwa Akademickie i Profesjonalne, Warszawa 2010.

Lipiński A., Komentarz do art. 22-23 ustawy z dnia 9 czerwca 2011 r. Prawo geologiczne i górnicze, „Prawne Problemy Górnictwa i Ochrony Środowiska”, 2020, nr 1-2, s. 41-61.

Lipiński A., Planowanie przestrzenne jako instrument ochrony złóż kopalin, w: Zrównoważony rozwój jako czynnik determinujacy prawne podstawy zarządzania geologicznymi zasobami środowiska, red. G. Dobrowolski, Agencja Reklamowa TOP, Katowice 2016, s. 123-155.

Łętowski J., Administracja i obywatele (refleksje rocznicowe), „Państwo i Prawo” 1984, nr 7.

Łętowski J., Administracja. Prawo. Orzecznictwo sądowe, Zakład Narodowy im. Ossolińskich, Wrocław-Warszawa-Kraków-Gdańsk—Łódź 1985.

Mikosz R., Własność kopalin i własność wód - kilka uwag o konstrukcji prawnej, „Prawne Problemy Górnictwa i Ochrony Środowiska" 2020, nr 1-2, s. 63-79.

Misztal M., Problematyka wartości w socjologii, PWN, Warszawa 1980 .

Mucha J., Konflikt i społeczeństwo: z problematyki konfliktu spolecznego we wspótczesnych teoriach zachodnich, PWN, Warszawa 1978.

Mucha J., Konfliktowe modele społeczeństwa we wspótczesnej socjologii niemarksistowskiej próba typologii, „Studia Socjologiczne” 1975, nr 1.

Nowy Leksykon PWN, red. A. Dyczkowski, PWN, Warszawa 1998.

Prawo rzymskie. Słownik encyklopedyczny, red. W. Wołodkiewicz, Wiedza Powszechna, Warszawa 1986.

Radecki G., Pojęcie wydobywania kopalin ze złóż w kontekście prawa wodnego, „Prawne Problemy Górnictwa i Ochrony Środowiska" 2020, nr 1—2, s. 127-141.

Rowiński T., Interes prawny $w$ procesie cywilnym $i$ w postępowaniu nieprocesowym, Wydawnictwo Prawnicze, Warszawa 1971.

Skrzydło-Niżnik I., Model ustroju samorzadu terytorialnego w Polsce na tle zagadnień ustrojowego prawa administracyjnego, Wydawnictwo Uniwersytetu Jagiellońskiego, Kraków 2007.

Stownik języka polskiego Wydawnictwa Naukowego PWN, https://sjp.pwn.pl/szukaj/interes.html [dostęp: 13.03.2021].

Stownik wyrazów obcych, red. J. Tokarski, PWN, Warszawa 1972.

Stefaniuk M., Interes państwa i jego odpowiedniki w orzecznictwie polskiego Trybunatu Konstytucyjnego, w: Pojęcie interesu w naukach prawnych, prawie stanowionym i orzecznictwie 
sadowym Polski i Ukrainy, red. A. Korybski, M.W. Kostyckij, L. Leszczyński, Wydawnictwo Uniwersytetu Marii Curie-Skłodowskiej, Lublin 2006.

Suwaj P.J., Konflikt interesów w administracji publicznej, Wolters Kluwer Polska, Warszawa 2009.

Wiatr J.J., Spoleczeństwo. Wstęp do socjologii systematycznej, PWN, Warszawa 1977.

Wilczyńska A., Interes publiczny w prawie stanowionym i orzecznictwie Trybunału Konstytucyjnego, „Przegląd Prawa Handlowego” 2009, nr 6, s. 48-55.

Wyrzykowski M., Pojęcie interesu społecznego w prawie administracyjnym, Wydawnictwo UW, Warszawa 1986.

Zimmermann J., Prawo administracyjne, Wolters Kluwer Polska, Warszawa 2012.

Żurawik A., Interes publiczny w prawie gospodarczym, Wydawnictwo C.H.Beck, Warszawa 2013.

Artur Żurawik

\title{
Conflicts of public interests in connection with the mining activities of hard coal mines
}

\author{
Summary
}

Mining activity remains crucial for protecting the state's interests as a whole and ensuring its energy security. Coal deposits of various types are a national good, but exhaustible. On the one hand, they should be taken care of when running a rational extractive economy especially in the context of the constitutional principle of sustainable development, on the other hand, however, one should be conscious of possible conflicts of interests arising in the context of such activities. After all, extractive activity is not irrelevant either to the environment or to the various entities interests and these could be both individual and public. A particularly interesting case could be that of a conflict of public interests of the State Treasury and local government units, which are exposed to the negative effects of the functioning of mines. Similar conflicts of interests arise in relations between the European Union and some Member States, which base their energy security on coal. These selected aspects are the subject of this study.

Key words: coal mining, conflicts of interests, the principle of sustainable development, economic activity, mines

\section{Артур Журавик}

\section{Конфликт общественных интересов в связи с горнодобывающей деятельностью шахт каменного угля}

\author{
Резюме
}

Горнодобывающая деятельность необходима для защиты интересов государства в целом и сохранения его энергетической безопасности. Угольные месторождения различных типов являются национальным достоянием, но при этом относятся к исчерпаемым. С одной стороны, необходимо о них заботиться, осуществляя рациональную эксплуатацию, 
особенно в контексте конституционного принципа устойчивого развития, но с другой стороны, важно знать о возможных конфликтах интересов, возникающих в результате осуществления такой деятельности. Действительно, горнодобывающая деятельность не является нейтральной ни для окружающей среды, ни для интересов различных субъектов. Речь может идти как об индивидуальных, так и государственных интересах. Особенно интересным может быть конфликт государственных интересов государственного казначейства и местными самоуправлениями, которые подвергаются негативному воздействию шахт. Подобные конфликты интересов возникают в отношениях между Европейским союзом и некоторыми государствами-членами, связывающими свою энергетическую безопасность с углем. Именно эти конкретные аспекты рассматриваются в рамках данного исследования.

Ключевые слова: угледобывающая промышленность, конфликты интересов, принцип устойчивого развития, экономическая деятельность, шахты

Artur Żurawik

\section{Conflitti di interessi pubblici in relazione alle attività di estrazione del carbone}

\section{Sommario}

L'attività mineraria è necessaria per proteggere gli interessi dello Stato nel suo insieme e per mantenere la sua sicurezza energetica. I depositi di vari tipi di carbone sono un bene nazionale, ma sono esauribili. Da un lato, è necessario prendersi cura di essi, conducendo un'economia mineraria razionale, soprattutto nel contesto del principio costituzionale dello sviluppo sostenibile, ma dall'altro lato è necessario essere consapevoli dei possibili conflitti di interesse che possono sorgere come risultato di tale attività. L'attività estrattiva non è indifferente né per l'ambiente né per gli interessi delle varie entità. Può riguardare sia interessi individuali che pubblici. Il conflitto di interessi pubblici dell'erario e delle unità governative locali, che sono esposte agli effetti negativi delle operazioni minerarie, può essere un caso particolarmente interessante. Simili conflitti di interessi appaiono nelle relazioni tra l'Unione Europea e alcuni dei suoi Stati membri che basano la loro sicurezza energetica sul carbone. Ecco gli aspetti selezionati che tratta questo studio.

Parole chiave: miniere di carbone, conflitti di interesse, principio dello sviluppo sostenibile, attività economica, miniere 